\section{Practice teaching: An inquiry into the experiences in developing an evaluation tool used in classroom observations}

\section{Wang, Wen-Lin}

Graduate Institute of Educational Leadership and Development, Fu Jen Catholic University, Taiwan (050878@mail.fju.edu.tw)

\section{Lin, Mei-Chin}

Graduate Institute of Educational Leadership and Development, Fu Jen Catholic University, Taiwan (041463@mail.fju.edu.tw)

\section{Ching, Gregory S.}

Graduate Institute of Educational Leadership and Development, Fu Jen Catholic University, Taiwan (gregory_ching@yahoo.com; 094478@mail.fju.edu.tw)

Received: 11 May 2015

Revised: 10 October 2015 Available Online: 17 October 2015

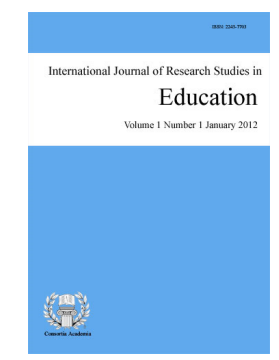

ISSN: 2243-7703 Online ISSN: 2243-7711

OPEN ACCESS

\title{
Abstract
}

Proper preparation prior to practice teachers' actual internship is deemed as an important part of the teacher development program. This presentation depicts the summary and findings of a semester-long action research study with 19 practice teachers (PT) undertaken in the fall semester of 2013. After finishing all their required credits, PTs needed to prepare themselves for their upcoming internship. In order to help make their internship fruitful and be able to learn as much as possible from their teacher mentor, an internship preparation course designed as an action research was created to support PTs in being able to determine specific classroom observation skills. Within the course, PTs were separated into 4 groups and tasked with organizing all the previous theories learned from other courses in order to determine the key features of a good classroom teacher. Afterwards, the researchers oriented the PTs with the problem-based learning (PBL) approach in creating a list of key features of a good classroom teacher. After a month of preparation, PTs were then assigned to undergo two months of classroom observations in a nearby elementary school. In addition, the PTs needed to do two practice teaching sessions before the end of the observation period. During the classroom observations and practice teaching, the PTs used their list of key features of a good classroom teacher to evaluate each other. Pre-post conferences were accomplished before and after each practice teaching session. Researcher observations, interview, and PTs' reflection logs were later collected and analyzed. Results indicate that PTs claimed that they are able to learn more within a PBL approach in developing an evaluation tool used in classroom observation as compared to the typical classroom discussion type setup. In sum, the process of classroom lectures presented in tandem with actual classroom observations and practice teaching has led to the enrichment of their overall pre-internship experiences, thus, helping them better prepare themselves for their future teaching career.

Keywords: teacher preparation; action research; problem-based learning; practice teacher; classroom observation 


\section{Practice teaching: An inquiry into the experiences in developing an evaluation tool used in classroom observations}

\section{Introduction}

Researches have shown that teachers have played an important role in most educational reform for the past decades (Campos, 2005). For the past few years, strong emphasis has been placed in research regarding teaching quality and effectiveness (Darling-Hammond, Wei, Andree, Richardson, \& Orphanos, 2009). Acknowledging that teacher quality matters in terms of students' overall achievements (Darling-Hammond, 2000b), with that having said, it is assumed that prior teacher preparations can strongly influence their future teaching career (Darling-Hammond, Chung, \& Frelow, 2002; Whitehurst, 2002).

In Taiwan, teacher preparation programs have grown from the traditional National (public) Normal Universities courses into certificate (or licensure) programs within regular national and private universities (Chou \& Ching, 2012). Similar to its western counterparts, teacher preparation in Taiwan has also undergone various policy changes focusing much on improving teacher quality (Darling-Hammond, 2005; Fwu \& Wang, 2002). In effect, these policy changes have brought about numerous teacher education reforms, which significantly impacted how pre-service teachers are being prepared (Lo, Hung, \& Liu, 2002).

Within the Teacher Education Act (enacted in 1994 and revised in 2011) is the provision that all pre-service teachers either enrolled in Normal universities or university based teacher preparation centers should undergo a 6 months (1 semester) school-based (field internship) practicum (Ministry of Education, 2011). To make the practicum fruitful, the researchers believed that proper preparation prior to the practice (pre-service) teachers' (PT) actual internship is deemed as an important part of the teacher development program. While various studies have reported that pre-service teachers' efficacy played a significant role in their future teaching career (Liaw, 2009; Lin \& Gorrell, 1997, 2001), the current study proposes that problem-based learning (PBL) should be able to help PT prepare and at the same time help develop their efficacy.

In light of the above mentioned issues, the current study shall summarize the findings of a semester-long action research with 19 PTs undertaken in the fall semester of 2013. Prior to the PTs' semester long internship, students need to take a preparation course inclusive of a PBL project, two months classroom observations and two practice teaching sessions in a nearby elementary school. It is hoped that by going through a carefully structured preparation program, PTs are able to prepare well for their upcoming internship. Initial research objectives are as follows:

How did the PTs perceive the entire internship preparation course?

$>\quad$ How did the PTs perceive the different factors used in classroom observation?

\section{Teacher preparation and problem-based learning}

As with the seminal literature suggests that teachers are not train, but they are prepared (Fox, 1968). Teacher preparation is seen as the process that requires reflection, cognition, re-organization, and integration on the part of the students, and not as a simple stimulus-response activity (or a series of experiences) (Fox, 1968, p. 113). The researchers posit that by undergoing a carefully structured process of preparation; connection between theory and practice are formed (Cochran-Smith \& Lytle, 2009; Rust, 2009; Rust \& Meyers, 2006).

Studies regarding the impact of PTs' pedagogical preparation; the various course subjects that deals with instructional methods and learning theories, towards their future teaching competencies are not that conclusive (Allen, 2003, p. 2; Wilson, Floden, \& Ferrini-Mundy, 2001, p. 12). However, in various occasions, significant 
An inquiry into the experiences in developing an evaluation tool used in classroom observations

difference was found with licensed and non-licensed teachers (Cochran-Smith et al., 2012; Darling-Hammond, 2000a, 2006; Fetler, 1999; Hawk, Coble, \& Swanson, 1985). Although these studies does indicate to some extent the importance of undergoing formal teacher preparation, no clear indications to which pedagogical intervention provides the most implications.

Within these few years, the concept of PBL has slowly been found in various teacher preparation studies. Such as in relation to teaching pedagogy (Brush et al., 2013; James, Rabe, \& Rosen, 2013), information technology literacy (Alexander, 2013), teaching mathematics (Martin, Grimbeek, \& Jamieson-Proctor, 2013), teaching Science, Technology, Engineering, and Mathematics (STEM) subjects (Mong \& Ertmer, 2013), group work (Barron, Preston-Sabin, \& Kennedy, 2013; Barron \& Wells, 2013), and teaching reading (Barron \& Wells, 2013), just to name a few.

PBL was popularized from the teaching medical students for the past decades (Barrows, 1994, 1996). PBL is said to promote student-centered and multidisciplinary education (Boud \& Feletti, 1997). Taking its roots from the benefits brought about by the practical experience in learning (Dewey, 1938). Savery (2006) defined PBL as instructional learner-centered approach that empowers learners to conduct research, integrate theory and practice, and apply knowledge and skills to develop a viable solution to a defined problem (p. 12). More specifically, within PBL, students work in small collaborative groups and learn what they need to know in order to solve a problem (Hmelo-Silver, 2004, p. 236). Taking note of the teacher preparation process as mentioned by Fox (1968), the researchers believed that PBL would provide a suitable opportunity for PTs to undergo reflection, cognition, re-organization, and integration.

Looking into the effects of PBL in preparing professionals, several studies have looked into its effectiveness. The highly cited works by Albanese and Mitchell (1993) and Vernon and Blake (1993) noted that medical students who undergoes PBL showed significant differences in terms of clinical problem solving skills, while exhibiting similar licensure examination scores as compared to traditional students. In a recent meta-analysis on nursing education, Shin and Kim (2013) noted that within the studies they reviewed, PBL showed significant positive effects towards nursing students' overall satisfaction with training, clinical education, and skill course. More meta-analyses have also shown the promised of long-term retention and performance improvement with the use of PBL (Berkson, 1993; Colliver, 2000; Dochy, Segers, Van den Bossche, \& Gijbels, 2003; Gijbels, Dochy, Van den Bossche, \& Segers, 2005; Kalaian, Mullan, \& Kasim, 1999; Schmidt, Molen, Winkel, \& Wijnen, 2009; Strobel \& van Barneveld, 2009; Walker \& Leary, 2009). Lastly, PBL works best when focusing on authentic situations, hence, the current study proposes the use of PBL approach in creating a list of key features of a good classroom teacher, while undergoing two months of classroom observations in a nearby elementary school.

\section{Methodology}

The current study is designed as an action research, wherein the proposed collaborative group works of PTs in an internship preparation course is able to diminish the theory-practice divide (Wenger, 1998; Wenger \& Lave, 2001; Wenger, McDermott, \& Snyder, 2002). Action researches are said to shortens the distance between theory and practice, so that participants of action research studies are able to determine and grasp the positive differences within their local educational contexts (Stringer, 2007). As with the recent increased use in teacher education (Cochran-Smith \& Lytle, 1999; Korthagen, Loughran, \& Russell, 2006) and teacher development (Ball \& Cohen, 1999; Putnam \& Borko, 2000; Rust, 2009; Rust \& Meyers, 2006), action researches have indeed provided a strong opportunity for teachers to examine the effectiveness of various teaching interventions.

\subsection{Participants}

The current study makes use of a group of PTs taking an internship preparation course during the fall semester of 2013 in a comprehensive private university located in Northern Taiwan. The participant of the study 
Wang, W.-L., Lin, M.-C., \& Ching, G. S.

is a class that comprised of 19 PTs; Table 1 shows the participants demography. The class size is deliberately kept to a minimum so as to maintain a healthy interaction amongst the students and their teacher.

Table 1

Participants demography $(N=19)$

\begin{tabular}{lllllll}
\hline & Male & \multicolumn{3}{c}{ Fotal } \\
& $n$ & $\%$ & $n$ & $\%$ & $n$ & $\%$ \\
\hline Participants & 3 & $3 \%$ & 16 & $17 \%$ & 19 & $20 \%$ \\
\hline
\end{tabular}

\subsection{Research process}

Typically, after students have finished all their required credits in the teacher preparation program, they are already deemed as ready for their semester long internship. However, in order to help make their internship fruitful and be able to learn as much as possible from their teacher mentor, an internship preparation course designed as an action research was created to support PTs in being able to determine specific classroom observation skills. Within the course, the 19 PTs were separated into 4 groups and tasked with organizing the key features of a good classroom teacher from all the previous theories learned within the entire teacher preparation program course subjects.

Afterwards, the researchers oriented the PTs with the PBL approach in creating a list of key features of a good classroom teacher. The list shall become the PTs basis on issues to look into during the following classroom observations. After a month of preparation, PTs were then assigned to undergo two months of classroom observations in a nearby elementary school. In addition, the PTs needed to do two practice teaching sessions before the end of the observation period. During the classroom observations and practice teaching, the PTs used their list of key features of a good classroom teacher to evaluate each other. Pre-post conferences were accomplished before and after each practice teaching session. Researcher observations, interview, and PTs' reflection logs were later collected and analyzed. In addition, a course evaluation survey was also administered after the semester. Data collected were analyzed using the Miles and Huberman (1994) method for generating meaning from transcribed and interview data. While, the course evaluation data were tabulated using the software Statistical Package for Social Science version 20.

\section{Results and findings}

\subsection{PTs' perception on the entire internship preparation course}

Analysis of the pre/post practice teaching conferences, observation, and reflection logs resulted in four (4) specific themes, namely: pre-class preparations, content knowledge, teaching pedagogy, and classroom management. Pre-class preparations quite related to lesson planning has been noted; if practiced correctly, to be important for teacher success (Farrell, 2002; John, 1991, 2006). PTs repeated mentioned during their post-practice teaching conferences the need for adequate time to prepare before their practice teaching.

As I observed the teacher teaching (during the classroom observations), I noticed that she knows the topic by heart. I think she should have spent some time in preparing the lessons - PT03

Being prepared before teaching is very important, I really have to devote my time in planning the lesson. Besides, I have to learn about the topic and try to focus on motivating the students PT07

The previous statement actually shows another important aspect of preparation, which is to know your students. 
An inquiry into the experiences in developing an evaluation tool used in classroom observations

Understanding how to motivate students to listen; a sort of ice breaking, has been the key feature on how to begin a lesson. PTs argue that catching the students' attention is important in making a lesson effective.

I think knowing the interest of my students is the key to having a good class interaction. I must put myself in the place of the students. What would catch their attention? I would ask myself, if I were the one sitting in the classroom, what lesson would be interesting? I can only achieve this thru prior preparation and keen observation - PT12

Some students even mentioned the need for rehearsing the lesson; a sort of playing out the entire process of the lesson, before the actual practice teaching session.

After I planned my lesson, I will then start to practice. Sometimes even in front of a mirror and recording myself. I am so tense; this is my first formal teaching - PT03

My practice teaching did not went well, I follow my lesson plan, but the students are not that responsive, so I end up teaching all the lessons with still time to spare. I should have planned some other activities just in case I would have extra time - PT09

As mentioned earlier having a lesson plan is important. However, sometimes even the most carefully planned lesson does not end well; as seen by the experience of PT09. Actually, during PT09's practice teaching, the students seems quite passive; non-reactive to the PT's questions. Hence, the PT has no recourse but to continue the lesson. It is therefore important to prepare and have a lesson plan in hand, but there is also a need to have some additional activities or strategies in motivating the students.

Besides pre-preparation, content knowledge is also very important (Shulman, 1986, 1987). During the PTs' preparation, knowing what to teach is quite a crucial part of the process.

Although I already know about the subject matter, I still have to read about the lesson topic. Another key is to have the content easily understood by the students, while having a creative approach to teaching the lesson - PT03

What I usually do is to draw a sort of concept map of the lesson, this help me prepare for the lesson. This map can also serve as a connection diagram, in this way, I can tell what previous lessons the students know and what future lessons they need to learn - PT10

Not only knowing what to teach, but also the sequence of the lessons is seen as important part of teaching (Freeman, 1982). The notion of reviewing (or recall) the previous lessons and make the proper connection, hence make teaching more effective (Bliss, Askew, \& Macrae, 1996). These concepts are actually necessities in having an effective teaching pedagogy.

Teacher strategies or pedagogy have been one of the core focuses of the teacher preparation programs. Course subjects such as instructional methods and learning theories have provided PTs with the general background of teaching pedagogy. Besides the previously mentioned issues, PTs shared various issues regarding their two months classroom observation and practice teaching experiences. An issue kept arising is time management. PTs noted that it's hard to keep track with the time. Sometime, PTs tend to teach too fast, or some activities might drag the time.

I have to take note of the time; it is really hard to look at my watch every few minutes. However, I am afraid that I might be teaching too fast or too slow - PT09 
Wang, W.-L., Lin, M.-C., \& Ching, G. S.

I did not know why the activity lasts that long, it was supposed to last only for 5 minutes. But the students are not yet finish answering the questions - PT01

The key is to know the ability of the students, so as to design the appropriate level of activities and connect the lesson to familiar concepts. Lessons that take too long might become boring to some students.

I also noticed that some students are bored when the lesson is too long, I think proper planning and making the lesson easy to understood, such as connecting to practical daily life activities PT03

PTs in various occasions also noted that when in front of the students, besides saying the right words, avoiding verbal jargons, and having a clear blackboard penmanship, proper teaching attitude must be observed. Such as having a good interaction with students, give the students some time to think about the activities (and not give the answer immediately), move around the class (avoid staying only in one part of the class), proper eye contact with students, take note of students who are not participating in class discussions, and many others.

After I watched the video taken during my practice teaching, I just noticed that I kept repeating some verbal jargons that I am usually unaware of it. Besides my blackboard penmanship is not clear, it is a good thing I taped the session - PT04

It is really hard to stand in front of the students; I immediately forgot the words that I am supposed to say. It is a good thing I have a clear lesson plan. One more thing is that I have to maintain healthy eye contact with the students and be alert of the students who are not paying attention - PT06

In addition, PTs also noted the effective use of technology. However, some PTs have become too much dependent on power-points and when technology is unavailable the lessons might be interrupted. PTs must remember to have a backup plan in case of technology failure, similar with having additional (or removal of) activities when running out or having too much time during lessons.

I did remember to check the computer and projector the day before my practice teaching, but somehow the computer did not work during the actual session. It took me around 15 minutes to connect the laptop to the projector, which wasted precious classroom time - PT15

Another significant issue is the ability to use various types of activities (including individual and group work). PTs claimed that the lessons should include various types of activities, group works are also encourage.

Students enjoy various types of activities; sometimes I will separate them into small group and some other times individual activities. As long as students are able to enjoy learning, I think it is fine-PT18

One more important issue is the having someone to consult with during difficulties. PTs claimed that their teacher mentors during the classroom observations, including their course teacher and classmates are all valuable resources. Sharing of teaching (including practice teaching) experiences is seen as helpful in improving the PTs pedagogical preparations. Lastly, PTs noted that classroom management as one of the difficult aspects of teaching. Besides the various related issues already mentioned, trying to establish a class norm or rule with the students is seen as important way in creating a learning conducive atmosphere (Marzano, Marzano, \& Pickering, 2003).

As for the results of the course evaluation survey, Table 2 shows the results separated into as follows: internship preparation course, teaching pedagogy, teaching attitude, and teamwork and problem solving. The survey uses a 5 point Likert type scale with 5 as the highest value and 1 the lowest. For the overall satisfaction 
An inquiry into the experiences in developing an evaluation tool used in classroom observations

rating of the internship preparation course, the PTs rated an overall mean score of 4.33; which is quite high, denoting high satisfaction. With regards to the various internship preparation course items, PTs rated the item 'My teacher is able to promote higher order thinking skills' with the highest mean score of 4.47, followed by the item 'My teacher encourage us to work together and solve the problem at hand' with a mean score of 4.42 and the item 'My teacher guides us in using various sources of information to solve the problem at hand' with a mean score of 4.37, denoting the effects of the PBL group work done during the course.

For the teaching pedagogy, PTs rated an overall score of 3.82; denoting somewhat agreeing to their improvement of instructional methods. Two promising results were seen with the items 'I am able to use a teaching evaluation system to assess myself and others' with a mean score of 4.11 and the item 'I am able to create my own teaching philosophy and practical knowledge through reflection and interaction with others' with a mean score of 4.05, such results indicate that thereby undergoing the PBL course work, students are able to effectively use the list they have created. While these two items both have the lowest mean of 3.54, items ' $I$ am to create an effective teaching strategy based on various educational theories and actual experiences' and 'I have enough teaching methods and strategies in achieving my lesson objectives' denoting the need for further improvements in their teaching ability, which is quite acceptable since they are in their preparation for their later internship.

For the teaching attitude, PTs rated the overall mean score of 4.37, which is the highest among the four factors. PTs claimed that they are quite enthusiastic in teaching with the item 'I am willing help my students learn' with a mean score of 4.74, 'I believed that teaching is a meaningful profession' with a mean score of 4.68, and 'I am eager to teach' with a mean score of 4.42, denoting their eagerness to engage in teaching. However, PTs are still not quite adept with teaching with the item 'I have faith in my ability to teach' having a mean score of 3.68, denoting the lack of self-confidence in their own teaching ability.

Lastly, for the factor teamwork and problem solving, PTs rated an overall mean score of 4.08, indicating agreeing that they have improved in some ways regarding cooperative work and solving difficulties. Items ' $I \mathrm{am}$ willing to cooperate and communicate with my peers' and 'I am able to use information from multiple sources to solve a problem' both have the highest mean score with 4.26, again resulting from the PBL work, while the items 'I am able to control and plan for my studies' and 'I am able to think critically' both with a mean score of 3.84, which is the lowest of all the items. These results denotes that PBL is quite an effective way of engaging the PTs into working in groups and enhancing their problem-solving capabilities. However, they still need more opportunity to practice their teaching pedagogy.

Table 2

Results of the evaluation survey $(N=19)$

\begin{tabular}{|c|c|c|c|c|c|c|}
\hline Factors/Items & VA & $\mathrm{A}$ & $\mathrm{N}$ & $\mathrm{D}$ & VD & Mean \\
\hline \multicolumn{7}{|l|}{ Internship preparation course } \\
\hline $\begin{array}{l}\text { My teacher guides us in using various sources of information to solve } \\
\text { the problem at hand }\end{array}$ & 9 & 8 & 2 & 0 & 0 & 4.37 \\
\hline My teacher encourage us to interact and discuss with each other & 10 & 5 & 4 & 0 & 0 & 4.32 \\
\hline $\begin{array}{l}\text { My teacher is able to promote an open and trusting learning } \\
\text { atmosphere. }\end{array}$ & 8 & 6 & 5 & 0 & 0 & 4.16 \\
\hline My teacher is focus in listening to out difficulties & 9 & 6 & 4 & 0 & 0 & 4.26 \\
\hline My teacher is able to promote higher order thinking skills & 11 & 6 & 2 & 0 & 0 & 4.47 \\
\hline $\begin{array}{l}\text { My teacher encourage us to work together and solve the problem at } \\
\text { hand }\end{array}$ & 9 & 9 & 1 & 0 & 0 & 4.42 \\
\hline \multicolumn{6}{|c|}{ Total } & 4.33 \\
\hline
\end{tabular}


Wang, W.-L., Lin, M.-C., \& Ching, G. S.

Table 2 ... continued

\begin{tabular}{|c|c|c|c|c|c|c|}
\hline Factors/Items & VA & $\mathrm{A}$ & $\mathrm{N}$ & $\mathrm{D}$ & VD & Mean \\
\hline Teaching pedagogy & & & & & & \\
\hline $\begin{array}{l}\text { I am able to use the educational theories that I learnt to analyze and } \\
\text { explain the things that I observed during class }\end{array}$ & 3 & 11 & 5 & 0 & 0 & 3.89 \\
\hline $\begin{array}{l}\text { I am to create an effective teaching strategy based on various } \\
\text { educational theories and actual experiences }\end{array}$ & 1 & 8 & 10 & 0 & 0 & 3.53 \\
\hline $\begin{array}{l}\text { I am able to use a teaching evaluation system to assess myself and } \\
\text { others }\end{array}$ & 4 & 13 & 2 & 0 & 0 & 4.11 \\
\hline $\begin{array}{l}\text { I am able to create my own teaching philosophy and practical } \\
\text { knowledge through reflection and interaction with others }\end{array}$ & 3 & 14 & 2 & 0 & 0 & 4.05 \\
\hline $\begin{array}{l}\text { I have enough teaching methods and strategies in achieving my lesson } \\
\text { objectives }\end{array}$ & 2 & 6 & 11 & 0 & 0 & 3.53 \\
\hline $\begin{array}{l}\text { I am able to provide a solution for the teaching difficulties I } \\
\text { encountered }\end{array}$ & 2 & 11 & 6 & 0 & 0 & 3.79 \\
\hline
\end{tabular}

Teaching attitude
I am eager to teach
I enjoy teaching
I believed that teaching is a meaningful profession
I have faith in my ability to teach
I am willing help my students learn

Teamwork and problem solving

I am willing to share and discuss with others

I am willing to cooperate and communicate with my peers

I have good interactions with my peers

I am able to control and plan for my studies

I am able to use information from multiple sources to solve a problem

I am able to think critically

I am capable in solving a problem

Total

\begin{tabular}{|c|c|c|c|c|c|c|}
\hline & 8 & 11 & 0 & 0 & 0 & 4.42 \\
\hline & 8 & 9 & 2 & 0 & 0 & 4.32 \\
\hline & 13 & 6 & 0 & 0 & 0 & 4.68 \\
\hline & 2 & 10 & 6 & 1 & 1 & 3.68 \\
\hline & 14 & 5 & 0 & 0 & 0 & 4.74 \\
\hline Total & & & & & & 4.37 \\
\hline
\end{tabular}

Note. Very much agrees $(\mathrm{VA})=5$, Agree $(\mathrm{A})=4$, Neither $(\mathrm{N})=3$, Disagree $(\mathrm{D})=2$, and Very much disagrees $(\mathrm{VD})=1$

\subsection{PTs' perception on the different important factors of classroom observation}

The results for the different classroom observation factors are the outcomes of the PTs PBL work. Results can be organized into five (5) factors, namely: lesson design and teaching strategy, use of educational technology, classroom management, teaching style, and effective use of evaluation/assessment. Looking at table 3, it seems that not all of the groups have similar factors, however, students just tends group the items under different factors, while still having similar core conceptual ideas.

Lesson design and teaching strategies consists of items that are instruction related, such as: lesson motivation, connection to previous lessons, clear lesson objectives, time management, lessons suitable for the students' level of understanding, various lesson activities (including group work), practical easy to understood samples, and many others. While, the factor Use of educational technologies consists of items related to use of visual aids and information technology in making the lessons more interesting. Actually some of the groups have included this in the previous factor of lesson design and teaching strategies. An important note is that the combination of these two factors makes up almost half of the classroom observation items, denoting its importance.

The remaining three factors are actually quite related with each other. Classroom management consists of items on how to handle the students such as: how students are doing with their lessons, classroom rules and norms, and students' in-class behaviors. Teaching styles include the items how the teacher talks and interact with students. While, the final factor effective use of evaluation/assessment includes the items about the 
An inquiry into the experiences in developing an evaluation tool used in classroom observations appropriate design of assessments; including various types of assessments and giving the appropriate feedbacks.

\section{Table 3}

Classroom observation factors

\begin{tabular}{lllll}
\hline \multicolumn{1}{c}{ Factors/Groups } & 1 & 2 & 3 & 4 \\
\hline lesson design and teaching strategy & $*$ & $*$ & $*$ & $*$ \\
use of educational technology & $*$ & $*$ & $*$ & $*$ \\
classroom management & $*$ & $*$ & $*$ & $*$ \\
teaching style & $*$ & $*$ & $*$ & $*$ \\
effective use of evaluation/assessment & & $*$ & $*$ & $*$ \\
\hline
\end{tabular}

\section{Conclusions}

Results indicate that PTs claimed that they are able to learn more within a PBL approach in developing an evaluation tool used in classroom observation as compared to the typical classroom discussion type setup. In sum, the process of classroom lectures presented in tandem with actual classroom observations and practice teaching has led to the enrichment of their overall pre-internship experiences, thus, helping them better prepare themselves for their future teaching career.

\section{References}

Albanese, M. A., \& Mitchell, S. (1993). Problem-based learning: A review of the literature on its outcomes and implementation issues. Academic Medicine, 68(1), 52-81. http://dx.doi.org/10.1097/00001888-199301000-00012

Alexander, B. (2013). Problem-based learning and beyond. In R. McBride \& M. Searson (Eds.), Proceedings of Society for Information Technology \& Teacher Education International Conference 2013 (pp. 3573-3576). Chesapeake, VA: Association for the Advancement of Computing in Education.

Allen, M. (2003). Eight questions on teacher preparation: What does the research say? A summary of findings. Denver, CO: Education Commission of the States.

Ball, D. L., \& Cohen, D. K. (1999). Developing practice, developing practitioners: Towards a practice-based theory of professional education. In L. Darling-Hammond \& G. Sykes (Eds.), Teaching as the learning profession: Handbook of policy and practice (pp. 3-32). San Francisco, CA: Jossey Bass.

Barron, L., Preston-Sabin, J., \& Kennedy, D. (2013). Problem-based learning for the pre-service teacher. SRATE Journal, 22(2), 39-45.

Barron, L., \& Wells, L. (2013). Transitioning to the real world through problem-based learning: A collaborative approach to teacher preparation. Journal of Learning in Higher Education, 9(2), 13-17.

Barrows, H. S. (1994). Practice-based learning: Problem-based learning applied to medical education. Springfield: Southern Illinois University School of Medicine.

Barrows, H. S. (1996). Problem-based learning in medicine and beyond: A brief overview. In L. Wilkerson \& W. Gijselaers (Eds.), Bringing problem-based learning to higher education: Theory and practice (Vol. 68, pp. 3-11). San Francisco, CA: Jossey-Bass. http://dx.doi.org/10.1002/tl.37219966804

Berkson, L. (1993). Problem-based Learning: Have the expectations been met? Academic Medicine, 68(10), S79-S88. http://dx.doi.org/10.1097/00001888-199310000-00053

Bliss, J., Askew, M., \& Macrae, S. (1996). Effective teaching and learning: Scaffolding revisited. Oxford Review of Education, 22(1), 1996. http://dx.doi.org/10.1080/0305498960220103

Boud, D., \& Feletti, G. (1997). The challenge of problem-based learning (2nd ed.). London: Kogan Page.

Brush, T., Glazewski, K., Ottenbreit-Leftwich, A., Saye, J., Zhang, Z., \& Shin, S. (2013). The PBL-TECH Project: Web-based tools and resources to support problem-based learning in pre-service teacher education. In R. McBride \& M. Searson (Eds.), Proceedings of Society for Information Technology \& Teacher Education International Conference 2013 (pp. 3841-3849). Chesapeake, VA: Association for the Advancement of Computing in Education. 
Wang, W.-L., Lin, M.-C., \& Ching, G. S.

Campos, M. R. (2005). Passive bystanders or active participants? The dilemmas and social responsibilities of teachers. In F. Reimers, M. Carnoy, J. J. Brunner, A. Panneflek, Á. Marchesi, G. N. d. Mello \& A. L. Machado (Eds.), PRELAC Journal: Teacher involvement in educational change (pp. 6-23). Chile: UNESCO.

Chou, C. P., \& Ching, G. S. (2012). Taiwan education at the crossroad: When globalization meets localization. New York, USA: Palgrave Macmillan. http://dx.doi.org/10.1057/9780230120143

Cochran-Smith, M., Cannady, M., Mceachern, K. P., Mitchell, K., Piazza, P., Power, C., et al. (2012). Teachers' education and outcomes: Mapping the research terrain. Teachers College Record, 114, 1-49.

Cochran-Smith, M., \& Lytle, S. (1999). The teacher research movement: A decade later. Educational Researcher, 28(7), 15-25. http://dx.doi.org/10.3102/0013189X028007015

Cochran-Smith, M., \& Lytle, S. (2009). Inquiry as stance. Practitioner research for the next generation. New York: Teachers College.

Colliver, J. A. (2000). Effectiveness of problem-based learning curricula: Research and theory. Academic Medicine, 75(3), 259-266. http://dx.doi.org/10.1097/00001888-200003000-00017

Darling-Hammond, L. (2000a). Reforming teacher preparation and licensing: Debating the evidence. Teachers College Record, 102, 28-56. http://dx.doi.org/10.1111/0161-4681.00047

Darling-Hammond, L. (2000b). Teacher quality and student achievement: A review of state policy evidence. Education Policy Analysis Archives, 8(1), 1-42. http://dx.doi.org/10.14507/epaa.v8n1.2000

Darling-Hammond, L. (2005). Teaching as a profession: Lessons in teacher preparation and professional development. Phi Delta Kappan, 87(3), 237-240. http://dx.doi.org/10.1177/003172170508700318

Darling-Hammond, L. (2006). Powerful teacher education: Lessons from exemplary programs. San Francisco, CA: Jossey-Bass.

Darling-Hammond, L., Chung, R., \& Frelow, F. (2002). Variation in teacher preparation: How well do different pathways prepare teachers to teach? Journal of Teacher Education, 53, 286-302. http://dx.doi.org/10.1177/0022487102053004002

Darling-Hammond, L., Wei, R. C., Andree, A., Richardson, N., \& Orphanos, S. (2009). Professional learning in the learning profession: A status report on teacher development in the United States and abroad. Washington, DC: National Staff Development Council.

Dewey, J. (1938). Experience and education. New York: Macmillan.

Dochy, F., Segers, M., Van den Bossche, P., \& Gijbels, D. (2003). Effects of problembased learning: A meta-analysis. Learning and Instruction, 13, 533-568. http://dx.doi.org/10.1016/S0959-4752(02)00025-7

Farrell, T. S. C. (2002). Lesson planning. In J. C. Richards \& W. A. Renandya (Eds.), Methodology in language teaching: An anthology of current practice (pp. 30-39). New York, NY: Cambridge University Press. http://dx.doi.org/10.1017/CBO9780511667190.006

Fetler, M. (1999). High school staff characteristics and mathematics test results. Education Policy Analysis Archives, 7(9), 1-21. http://dx.doi.org/10.14507/epaa.v7n9.1999

Fox, W. (1968). Let's not "train" teachers. College Teaching, 16(2), 113. http://dx.doi.org/10.1080/00193089.1968.10532721

Freeman, D. (1982). Observing teachers: Three approaches to in-service training and development. TESOL Quarterly, 16(1), 21-28. http://dx.doi.org/10.2307/3586560

Fwu, B.-J., \& Wang, H.-H. (2002). From uniformity to diversification: transformation of teacher education in pursuit of teacher quality in Taiwan from 1949 to 2000. International Journal of Educational Development, 22(2), 155-167. http://dx.doi.org/10.1016/S0738-0593(01)00019-0

Gijbels, D., Dochy, F., Van den Bossche, P., \& Segers, M. (2005). Effects of problem-based learning: A meta-analysis from the angle of assessment. Review of Educational Research, 75(1), 27-61. http://dx.doi.org/10.3102/00346543075001027

Hawk, P. P., Coble, C. R., \& Swanson, M. (1985). Certification: It does matter. Journal of Teacher Education, 36(3), 13-15. http://dx.doi.org/10.1177/002248718503600303

Hmelo-Silver, C. E. (2004). Problem-based learning: What and how do students learn? Educational Psychology 
An inquiry into the experiences in developing an evaluation tool used in classroom observations Review, 16(3), 235-266. http://dx.doi.org/10.1023/B:EDPR.0000034022.16470.f3

James, R., Rabe, B., \& Rosen, D. (2013). What role can teacher education programs play in making inquiry based learning an instructional norm. In EDULEARN13 Proceedings (pp. 5285-5296): IATED.

John, P. D. (1991). A qualitative study of British student teachers' lesson planning perspectives. Journal of Education for Teaching: International research and pedagogy, 17(3), 301-320. http://dx.doi.org/10.1080/0260747910170307

John, P. D. (2006). Lesson planning and the student teacher: Re-thinking the dominant model. Journal of Curriculum Studies, 38(4), 483-498. http://dx.doi.org/10.1080/00220270500363620

Kalaian, H. A., Mullan, P. B., \& Kasim, R. M. (1999). What can studies of problem based learning tell us? Synthesizing and modeling PBL effects on National Board of Medical Examination performance: Hierarchical Linear Modeling meta-analytic approach. Advances in Health Sciences Education, 4, 209-221. http://dx.doi.org/10.1023/A:1009871001258

Korthagen, F. A., Loughran, J., \& Russell, T. (2006). Developing fundamental principles for teacher education programs and practices. Teaching and Teacher Education, 22(8), 1020-1041. http://dx.doi.org/10.1016/j.tate.2006.04.022

Liaw, E.-C. (2009). Teacher efficacy of pre-service teachers in Taiwan: The influence of classroom teaching and group discussions. Teaching and Teacher Education, 25(1), 176-180. http://dx.doi.org/10.1016/j.tate.2008.08.005

Lin, H.-L., \& Gorrell, J. (1997). Pre-service teachers' efficacy beliefs in Taiwan. Paper presented at the Annual Meeting of the Mid-South Educational Research Association.

Lin, H.-L., \& Gorrell, J. (2001). Exploratory analysis of pre-service teacher efficacy in Taiwan. Teaching and Teacher Education, 17(5), 623-635. http://dx.doi.org/10.1016/S0742-051X(01)00018-X

Lo, J.-J., Hung, C.-C., \& Liu, S.-T. (2002). An analysis of teacher education reform in Taiwan since 1994 and its potential impact on the preparation of mathematics teachers at the elementary school level.

International Journal of Educational Research, 37(2), 145-159. http://dx.doi.org/10.1016/S0883-0355(02)00057-5

Martin, D. A., Grimbeek, P., \& Jamieson-Proctor, R. (2013). Measuring problem-based learning's impact on pre-service teachers' mathematics pedagogical content knowledge. Paper presented at the 2nd International Higher Education Teaching And Learning Conference (IEAA 2013): Engaging Innovative Pedagogical Practice and Research in Higher Education.

Marzano, R. J., Marzano, J. S., \& Pickering, D. J. (2003). Classroom management that works: Research-based strategies for every teacher. Alexandria, VA: ASCD.

Miles, M., \& Huberman, M. (1994). Qualitative data analysis (2nd ed.). Beverly Hills, CA: Sage.

Ministry of Education. (2011). 師資培育法施行細則 [shī zī péi yù fă shī xíng xì zé]. Retrieved from http://edu.law.moe.gov.tw/LawContentDetails.aspx?id=FL008776

Mong, C. J., \& Ertmer, P. A. (2013). Addressing STEM education needs: The case for adopting a PBL approach. Educational Technology, 53(3), 12-21.

Putnam, R. T., \& Borko, H. (2000). What do new views of knowledge and thinking have to say about research on teacher learning? Educational Researcher, 29(1), 4-15. http://dx.doi.org/10.3102/0013189X029001004

Rust, F. (2009). Teacher research and the problem of practice. Teachers College Record, 111(8), 1882-1893.

Rust, F., \& Meyers, E. (2006). The bright side: Teacher research in the context of educational reform and policymaking. Teachers and Teaching: Theory and Practice, 12(1), 69-86. http://dx.doi.org/10.1080/13450600500365452

Savery, J. R. (2006). Overview of problem-based learning: Definitions and distinctions. Interdisciplinary Journal of Problem-Based Learning, 1(1). http://dx.doi.org/10.7771/1541-5015.1002

Schmidt, H. G., Molen, H. T. V. D., Winkel, W. W. R. T., \& Wijnen, W. H. F. W. (2009). Constructivist, problem-based learning does work: A meta-analysis of curricular comparisons involving a single medical school. Educational Psychologist, 44(4), 227-249. http://dx.doi.org/10.1080/00461520903213592 
Wang, W.-L., Lin, M.-C., \& Ching, G. S.

Shin, I.-S., \& Kim, J.-H. (2013). The effect of problem-based learning in nursing education: A meta-analysis. Advances in Health Sciences Education, 18(5), 1103-1120. http://dx.doi.org/10.1007/s10459-012-9436-2

Shulman, L. S. (1986). Those who understand: Knowledge growth in teaching. Educational Researcher, 15(2), 4-14. http://dx.doi.org/10.3102/0013189X015002004

Shulman, L. S. (1987). Knowledge and teaching: Foundations of the new reform. Harvard Educational Review, 57(1), 1-23. http://dx.doi.org/10.17763/haer.57.1.j463w79r56455411

Stringer, E. T. (2007). Action research (3rd ed.). Thousand Oaks, CA: Sage.

Strobel, J., \& van Barneveld, A. (2009). When is PBL more effective? A meta-synthesis of meta-analyses comparing PBL to conventional classrooms. Interdisciplinary Journal of Problem-Based Learning, 3(1). http://dx.doi.org/10.7771/1541-5015.1046

Vernon, D. T. A., \& Blake, R. L. (1993). Does problem-based learning work? A meta-analysis of evaluation research. Academic Medicine, 68(7), 550-563. http://dx.doi.org/10.1097/00001888-199307000-00015

Walker, A., \& Leary, H. (2009). A problem-based learning meta-analysis: Differences across problem types, implementation types, disciplines, and assessment levels. Interdisciplinary Journal of Problem-based Learning, 3(1), 6-28. http://dx.doi.org/10.7771/1541-5015.1061

Wenger, E. (1998). Communities of practice. Cambridge, UK: Cambridge University. http://dx.doi.org/10.1017/CBO9780511803932

Wenger, E., \& Lave, J. (2001). Situated learning: Legitimate peripheral participation. Cambridge, UK: Cambridge University Press.

Wenger, E., McDermott, R., \& Snyder, W. M. (2002). Cultivating communities of practice. Boston: Harvard Business School.

Whitehurst, G. J. (2002). Scientifically based research on teacher quality: Research on teacher preparation and professional development. Paper presented at the White House Conference on Preparing Tomorrow's Teachers.

Wilson, S. M., Floden, R. E., \& Ferrini-Mundy, J. (2001). Teacher preparation research: Current knowledge, gaps, and recommendations. Seattle, WA: Center for the Study of Teaching and Policy. 